\title{
INTERNASIONALISASI KONSEP PURIFIKASI DALAM MANHAJ TARJIH MUHAMMADIYAH ${ }^{1}$
}

\section{- M. Abdul Fattah Santoso}

Universitas Muhammadiyah Surakarta (UMS), Indonesia

Email: fattahsantoso@yahoo.com

\begin{abstract}
Abstrak
Tulisan ini akan membahas tentang kesiapan Muhammadiyah dalam memperkenalkan manhaj ijtihad di hadapan publik internasional. Kesiapan tersebut menyangkut kematangan konsep populer yang khas dan berkembang secara inheren pada metodologi ijtihad Muhammadiyah, yaitu purifikasi. Purifikasi yang pada mulanya ditafsirkan sebagai gerak formalisasi syariah, mengalami pergeseran makna menuju spiritualisasi syariah. Ruang lingkup yang menjadi jangkauan ijtihad Muhammadiyah saat ini, bukan hanya pada bidang hukum Islam, melainkan juga berbagai persoalan sosial dan humaniora. Ketika agama Islam yang genap dengan nilai-nilai kebajikan universal dianggap perlu untuk mengambil bagian dalam rangka menyelesaikan berbagai masalah global, maka Muhammadiyah juga dianggap telah siap mendesaminasikan pemikiran Islam progresif ke seluruh dunia.
\end{abstract}

Kata Kunci: Muhammadiyah, Internasionalisasi, Purifikasi, Manhaj Tarjih Muhammadiyah

Tulisan ini pernah dipresentasikan di Workshop bertajuk Internasionalisasi Pemikiran dan Gerakan Muhammadiyah, yang diselenggarakan Program Studi Pendidikan Agama Islam (PAI/Tarbiyah), Program Studi Mu'amalah/HES (Syariah), dan Program Studi Ilmu Al-Qur'an dan Tafsir (Ushuluddin), Fakultas Agama Islam, Universitas Muhammadiyah Surakarta (UMS), bekerjasama dengan Jaringan Intelektual Muda Muhammadiyah (JIMM) di UMS, pada 31 Oktober - 1 Nopember 2014. 


\section{Pendahuluan}

Indonesia dengan penduduk yang mayoritas beragama Islam, dengan jumlah terbanyak di dunia, telah menjadi tempat yang subur bagi berkembangnya pemikiran dan gerakan Islam. Banyak pemerhati keagamaan ingin mengikuti perkembangan pemikiran dan gerakan Islam yang berkembang di dalam negeri, namun seringkali terkendala oleh faktor bahasa. Hingga saat ini, belum banyak karya tulis tentang pemikiran dan gerakan Islam, termasuk Muhammadiyah, yang ditulis dalam bahasa internasional. Muhammadiyah dengan usianya yang melampaui satu abad, dengan kekayaan amal usahanya, terutama di bidang pendidikan, sosial dan kesehatan yang berkontribusi signifikan bagi pembangunan bangsa Indonesia, sudah saatnya untuk melakukan internasionalisasi pemikiran dan gerakannya. Untuk mengupayakan internasionalisasi yang dimaksud, maka diperlukan prakondisi, yaitu perkembangan pemikiran Muhammadiyah: "Apakah ia kondusif atau tidak bagi upaya internasionalisasi yang lebih menuntut keterbukaan dan toleransi di tengah keanekaragaman pemikiran di internal umat Islam dan eksternal peradaban dunia?"

Membahas pemikiran yang berkembang di Muhammadiyah bukan pekerjaan mudah. Hal itu disebabkan beberapa faktor, di antaranya: Pertama, pembahasannya yang seringkali bersifat historis dengan meniscayakan pada lintas waktu. Terentang dalam periode satu abad, sehingga berimplikasi pada keterbatasan data, terutama untuk sejumlah pemikiran yang datang di masa lalu. Kedua, pilihan cara penyajian bahasan: Apakah dengan menggunakan kategorisasi kasar berdasarkan periode waktu yang terhimpun dalam setiap periode sejumlah isu pemikiran atau dengan menggunakan pendekatan tematik, yaitu memilih sejumlah isu penting beserta penjelasan perkembangan pemikirannya. Ketiga, beberapa isu pemikiran yang berkembang di Muhammadiyah -walau sempat ditengarai stagnan- sangat banyak, sehingga memunculkan sejumlah pilihan: Semua wacana pemikiran yang layak, isu aktual, atau beberapa isu mendasar yang dengan memahaminya dapat mengantarkan pada pemahaman lain, seperti mengapa pergulatan pemikiran dalam suatu isu dapat terjadi. Keempat, pemikiran yang berkembang di Muhammadiyah dapat dipilah berupa gagasan intelektualnya atau pemikiran formal organisasinya.

Dengan menyadari beberapa kesulitan tersebut, kajian ini masih bersifat pendahuluan dengan melakukan sejumlah pilihan. Kajian pendahuluan ini lebih memilih pendekatan tematik daripada kategorisasi berdasarkan waktu. 
Sedangkan sejumlah isu yang akan dipilih adalah isu-isu yang mendasar. Menurut hemat penulis, beberapa isu mendasar itu adalah pemikiran tentang pemurnian Islam dan manhaj ijtihad. Disebut mendasar karena pemahaman terhadap pergulatan pemikiran keduanya akan memudahkan pemahaman terhadap perkembangan pemikiran yang lain. Kemudian, karena keterbatasan data, kajian pendahuluan ini lebih banyak merujuk pada sumber sekunder.

Ciri yang lain pada kajian pendahuluan ini, meski menekankan pendekatan tematik, namun deskripsinya tidak meninggalkan tahapan perkembangan. Sebagai ciri terakhirnya, perkembangan pemikiran yang disajikan akan melibatkan pemikiran formal organisasi dan gagasan intelektual yang berkembang di Muhammadiyah. Berikut ini deskripsi perkembangan pemikiran Muhammadiyah sebagai prakondisi bagi upaya internasionalisasi: (1) Membahas isu pemurnian Islam; (2) Membahas isu manhaj ijtihad; (3) Analisis; (4) Penutup.

\section{Pemikiran Pemurnian Islam}

Pemahaman mengenai pemurnian Islam yang kerap dimengerti umat Islam adalah kembali ke al-Qur'an dan al-Sunnah (al-rujû́ ila al-Qur'ân wa al-sunnah). Dari penelusuran terhadap kajian yang telah dilakukan, ternyata pemikiran tentang pemurnian Islam di Muhammadiyah dari awal berdirinya sampai memasuki abad ke-21 berkembang dalam tiga fase: (1) fase spiritualisasi syariah babak pertama (masa pendiri, Kiai Ahmad Dahlan); (2) fase formalisasi syariah (masa dominasi ahli syariah); dan (3) spiritualisasi syariah babak kedua (masa kepemimpinan generasi berpendidikan tinggi modern). ${ }^{2}$

Isu pemurnian Islam, yang merupakan pengaruh Wahabiah dan reformisme Rasyid Ridha, pada masa Kiai Ahmad Dahlan, lebih dipahami sebagai penyadaran peran umat dalam kehidupan sosial daripada sebagai pemberantasan praktik takhayul, bid'ah, dan ch[kh]urafat (TBC). Dari dokumen Fachroddin (1921) yang dikutip Abdul Munir Mulkhan, ${ }^{3}$ penyadaran peran umat tersebut dilakukan melalui pendidikan di sekolah, bincang-bincang di majelis perkumpulan, pendayagunaan sarana keagamaan (wakaf, masjid dan mushallah), serta pendayagunaan media massa. Spiritualisasi syariahnya dapat dilihat dari peran hati yang suci, di samping pikiran yang sehat. Sehingga dalam menerima kebenaran, Kiai Ahmad Dahlan menolak fanatisme keagamaan. Bagi dia, penyakit

Abdul Munir Mulkhan, Islam Murni dalam Masyarakat Petani (Yogyakarta: Bentang, 2000).

Mulkhan, Ibid., 
TBC telah mentradisi di tengah masyarakat Islam akibat kebodohan mereka. Dari itu, pendidikan adalah satu-satunya solusi yang akan menyelamatkan mereka. Lebih jauh, baginya, amal lahir (syariah) adalah akibat daya ruh agama yang didasari hati dan pikiran suci, sementara organisasi adalah instrumen pengembangan kesalehan hati-suci itu. Hati suci (dan pikiran sehat) bukan hanya pangkal memahami Islam, melainkan juga akar ibadah atau dasar hidup sosial dan agama, sehingga terbebas dari jerat kebodohan dan ikatan tradisi. ${ }^{4}$

Pada zamannya, menurut Kuntowijoyo, Kiai Ahmad Dahlan dan Muhammadiyah menghadapi tiga tantangan: modernisme, tradisionalisme dan Jawaisme. ${ }^{5}$ Tantangan modernisme dijawab oleh Ahmad Dahlan dengan pendirian sekolah, kepanduan dan asosiasi sukarela lainnya. Tradisionalisme diselesaikan melalui tablig (penyampaian pesan-pesan agama) dengan cara mengunjungi murid (salah satu karakteristik sekolah) yang waktu itu merupakan aib sosialbudaya, karena lazimnya guru adalah menunggu murid datang (salah satu tradisi pesantren). Di balik aib sosial-budaya itu, terdapat perlawanan tidak langsung terhadap dua hal yang dapat dikategorikan TBC, yaitu: pemujaan ulama (yang sering dipandang keramat), dan mistifikasi agama (menjadikan agama sesuatu yang misterius, tinggi dan hanya patut diajarkan oleh orang-orang terpilih).

Dengan tablig, penyiaran agama telah dibuat manusiawi dan tidak lagi merupakan proses yang memiliki unsur keramat. Dengan tablig, Islam yang semula dipandang misterius menjadi agama yang sederhana, terbuka, dan dapat dipelajari setiap orang. Melalui tablig, Kiai Ahmad Dahlan menggunakan metode aksi positif (mengedepankan amar ma'ruf) dan tidak secara frontal menyerang (nahi munkar) TBC.

Sementara dalam merespons Jawaisme, Kiai Ahmad Dahlan menggunakan metode yang sama dengan cara menghapuskan mitos-mitos (demitologisasi). Salah satu mitos yang hidup saat itu adalah bahwa keberuntungan disebabkan memelihara jimat dan tuyul (pesugihan) atau minta-minta di kuburan keramat. Oleh Kiai Ahmad Dahlan, berbagai mitos yang berkembang tersebut dihapus dengan ajaran bahwa keberuntungan adalah semata-mata kehendak Tuhan. Sementara salah satu jalan untuk meraihnya adalah shalat sunat. ${ }^{6}$

4 Ibid.,

5 Kuntowijoyo, "Pengantar: Jalan Baru Muhammadiyah," dalam Abdul Munir Mulkhan, Islam Murni dalam Masyarakat Petani (Yogyakarta: Bentang, 2000).

6 Kuntowijoyo, "Pengantar: Jalan Baru Muhammadiyah," Ibid., 
Kesalehan spiritual (hati-suci) a la Kiai Ahmad Dahlan tersebut ternyata telah membangkitkan partisipasi berbagai kalangan masyarakat, termasuk kaum nasionalis, abangan dan priyayi. Pada sisi lain, juga membangkitkan daya kreatif luar biasa dan sikap terbuka Kiai Ahmad Dahlan. Dalam perspektif Kuntowijoyo, Ahmad Dahlan tampaknya lebih memilih pendekatan kultural daripada struktural dalam melakukan perubahan sosial. ${ }^{7}$ Pendekatan kultural adalah perubahan sosial melalui perubahan perilaku dan cara berfikir individu. Sedangkan pendekatan struktural adalah perubahan sosial melalui perubahan perilaku kolektif dan struktur politik.

Sepeninggal Kiai Ahmad Dahlan, berkembang fase formalisasi syariah. Sebagai momentumnya adalah pendirian Majelis Tarjih, yaitu lembaga fatwa syariah di tubuh Muhammadiyah. Isu "pemurnian Islam" pada fase ini dipahami sebagai pemberantasan taqlid buta dan praktik TBC, pencukupan kepada apa yang diajarkan Nabi pada bidang akidah dan ibadah mahdhah, dan ideologisasi syariah menjadi doktrin perubahan sosial dan hubungan dengan negara. Kata kunci dari pemahaman ini adalah Islamisasi. Dalam praktiknya, fase ini telah melahirkan kesalehan syariah yang lebih bersifat lahiriah daripada spiritual a la Kiai Ahmad Dahlan, dan kebijakan ideologis organisasi yang tertuang dalam "Muqaddimah Anggaran Dasar Muhammadiyah" (1950/1951), "Kepribadian Muhammadiyah" (1962/1963), "Matan Keyakinan dan Cita-cita Hidup Muhammadiyah" (1969/1970), dan "Khittah Perjuangan Muhammadiyah" (1978). ${ }^{8}$

Meski begitu, formalisasi syariah bukan tanpa ekses. Pemberantasan TBC menjadi bersifat berlebihan, meluas ke bentuk tradisi yang tidak bisa disebut TBC, seperti membuka rapat dengan membaca Surat al-Fatihah dan melafalkan puji-pujian pada Nabi. Identifikasi "Islam murni" berubah menjadi sebuah pernyataan yang menyudutkan, yaitu asal bukan seperti NU. ${ }^{9}$ Ekses dominonya adalah "tidak diterimanya" Muhammadiyah di kalangan petani dan umat Islam yang mmpraktikkan TBC. Tentu saja, pada akhirnya masalah ini memunculkan disintegrasi sosial sebagai efek dari penerapan metode aksi frontal (mengedepankan nahi munkar) daripada metode aksi positif (amar ma'ruf).

Ideologisasi syariah sebagai doktrin perubahan sosial dan hubungan dengan negara sempat menjadikan Muhammadiyah terjebak dalam pendekatan struktural

$7 \quad$ Kuntowijoyo, Identitas Politik Umat Islam (Bandung: Mizan dan Majalah Ummat, 1997).

8 Sudarno Shobron (ed.), Studi Kemuhammadiyahan: Kajian Historis, Ideologi dan Organisasi (Surakarta: Lembaga Pengembangan Ilmu-Ilmu Dasar (LPID) Universitas Muhammadiyah Surakarta, 2006).

9 Mulkhan, Ibid., 
(perubahan sosial melalui perubahan perilaku kolektif dan struktur politik). Pada awal kemerdekaan RI, Muhammadiyah mendukung Islam sebagai dasar negara, kemudian aktif sebagai anggota istimewa Masyumi. Pada awal Orde Baru, Muhammadiyah membidani lahirnya Parmusi, dan akhirnya pada 1998 merekomendasikan ketuanya untuk mendirikan PAN. ${ }^{10}$

Secara individual, pendekatan struktural telah mendorong sebagian aktivisnya terlibat dalam banyak partai (bahkan menjelang pemilu 2009, aktivis mudanya mendirikan partai alternatif, Partai Matahari Bangsa (PMB), meski tidak berusia panjang) dan/atau menduduki berbagai posisi politik strategis.

Bila pendekatan struktural lebih menonjolkan syariah dan perubahan yang di luar (karena itu menggunakan pendekatan kekuasaan), maka pendekatan kultural menonjolkan hikmah dan perubahan di lingkup internal. Perubahan luar itu perlu (necessary), tetapi tidak mencukupi (sufficient) bila tidak dilengkapi dengan perubahan dalam, meski perubahan internal itu lebih sulit.

Fase ketiga, melalui tampilnya kepemimpinan generasi berpendidikan tinggi modern pada 1995 (era Amin Rais), pemahaman ide pemurnian Islam memasuki spiritualisasi syariah babak kedua. Momentumnya adalah perubahan nomenklatur Majelis Tarjih menjadi Majelis Tarjih dan Pengembangan Pemikiran Islam (MTPPI), meski sejak 2005 dimodifikasi menjadi "Majelis Tarjih dan Tajdid" (MTT) tanpa menafikan fungsi dan peranan MTPPI. Sebagai latarbelakang dari perubahan nomenklatur tersebut adalah: Pertama, perubahan substansi TBC (substansi TBC era berdirinya Muhammadiyah dan era agraris tidak sama dengan yang terjadi pada era industri/pembangunan); Kedua, munculnya sejumlah pendekatan keilmuan sosial-budaya baru terhadap isu-isu sejenis TBC yang telah menggeser apa yang dimaksud dengan TBC pada saat didefinisikan dahulu; Ketiga, keduanya (perubahan substansi TBC dan munculnya ragam pendekatan keilmuan sosial-budaya baru) menuntut ijtihad baru dari Muhammadiyah yang tidak lagi harus bersifat fiqih dan/atau kalam klasik-skolastik semata. ${ }^{11}$ Kalaupun pendekatan kalam digunakan, ia tidak dalam makna yang didominasi oleh pembahasan tentang Tuhan (dalam pengertian klasik), namun dalam makna pendekatan yang lebih mengacu pada fungsionalisasi nilai-nilai spiritualitas keTuhan-an dalam aplikasi kehidupan konkret.

10 Mulkhan, Ibid.; Sazali, Muhammadiyah $\mathcal{E}$ Masyarakat Madani (Jakarta: Pusat Studi Agama dan Peradaban (PSAP) Muhammadiyah, 2005).

11 M. Amin Abdullah, "Perkembangan Pemikiran Islam dalam Muhammadiyah: Perspektif Tarjih Pasca Muktamar Muhammadiyah Ke-43," dalam Berita Resmi Muhammadiyah, No. 05/1995-2000 (April 1996), h. 18-26. 
Dalam rangka spiritualisasi syariah babak dua, ide pemurnian Islam dimulai oleh MTPPI (dan dikembangkan lebih lanjut oleh MTT) dengan merekonstruksi metodenya (manhaj) yang tidak lagi terbatas pada tarjih atau pengambilan hukum, dan kemudian memperluas wilayah objek ijtihadnya di luar persoalanpersoalan yang terkait dengan akidah dan ibadah mahdhah.

\section{Pemikiran tentang Manhaj ljtihad}

Pemikiran tentang manhaj tidak kalah pentingnya. Kritik yang sering diungkapkan dan ditujukan pada gerakan atau organisasi yang mengusung semangat kembali ke al-Qur'an dan al-Sunnah adalah bahwa gerakan atau organisasi tersebut berhenti pada slogan, dan belum mengembangkan pada sisi metodologinya. $^{12}$

Pada posisi ini, Muhammadiyah mendapat kritik tersebut karena sampai sekarang masih dalam proses pembentukan. Setelah lebih dari setengah abad mempraktikkan tarjih dan ijtihad, baru pada 1989 Muhammadiyah memulai fase pertama proses formasi metodologinya dengan menyusun Pokok-pokok Manhaj Tarjih. Secara garis besar dirumuskan beberapa prinsip, antara lain: (1) sumber dalam beristidlâl; (2) ketidak-terkaitan pada satu mazhab tertentu; (3) penggunaan akal dalam menyelesaikan masalah duniawi; (4) dan yang terpenting adalah terumuskannya metode-metode ijtihad, yaitu: ijtihad bayânî, qiyâsî, dan istishlâhî. Ijtihad bayânî dipakai dalam rangka mendapatkan hukum dari nash (teks) dengan menggunakan dasar-dasar tafsir. Ijtihad qiyâsî digunakan dalam rangka untuk menetapkan hukum yang belum ada dalam nash, dengan memperhatikan kesamaan 'illat-nya. Sementara ijtihad istishlâhî digunakan untuk menetapkan hukum yang sama sekali tidak diatur dalam nash. ${ }^{13}$

Seiring dengan perubahan nomenklatur majelis menjadi Majelis Tarjih dan Pengembangan Pemikiran Islam (MTPPI) pada 2000, sebagai fase kedua, telah dirumuskan manhaj yang lebih komprehensif, dengan menggunakan berbagai pendekatan. Kalau pada fase pertama metode ijtihad diwujudkan dalam bentuk ijtihad bayânî, qiyâŝ̂, dan istishlâĥ̂ yang berorientasi pada nash al-Qur'an dan al-

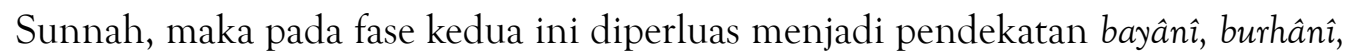

12 Din Syamsuddin, "Studium General Kolokium Nasional Pemikiran Islam PSIF UMM dan Al-Maun Institute” http://www.muhammadiyah.or.id/ (diakses pada 30 Oktober 2014).

13 Fathurrahman Djamil, “Tajdid Muhammadiyah pada Seratus Tahun Pertama”, dalam Mifedwil Jandra dan M. Safar Nasir (ed.), Tajdid Muhammadiyah untuk Pencerahan Peradaban (Yogyakarta: MTPPI PP Muhammadiyah bekerja sama dengan UAD Press, 2005), h. 83-106. 
dan 'irfânî. Pendekatan bayânî merupakan pendekatan yang menempatkan nash sebagai sumber kebenaran dan sumber norma untuk bertindak, sementara akal hanya menempati kedudukan yang sekunder dan berfungsi menjelaskan dan menjustifikasi nash yang ada. Pendekatan ini lebih didominasi oleh penafsiran gramatikal dan semantik. Dalam pandangan Muhammadiyah, pendekatan ini masih diperlukan dalam rangka menjaga komitmennya untuk kembali ke alQur'an dan al-Sunnah. ${ }^{14}$

Pendekatan burhân̂̂ merupakan pendekatan yang mengandalkan rasio dan pengalaman empiris sebagai sumber kebenaran dan sumber norma untuk bertindak. Dengan demikian, pendekatan ini lebih difokuskan pada pendekatan yang rasional dan argumentatif, berdasarkan dalil logika, dan tidak hanya merujuk pada teks, namun juga konteks. Pendekatan burhân̂̂ diperlukan Muhammadiyah dalam memahami dan menyelesaikan masalah yang termasuk urusan dunia (al-umûr al-dunyâwiyyah) untuk tercapainya kemaslahatan umat.

Belajar dari khazanah sejarah Islam, perpaduan antara pendekatan bayân̂̂ dan burhânî tidak banyak menimbulkan masalah. Sejak zaman klasik, upaya perpaduan telah coba dilakukan, misalnya oleh al-Gazali yang mengenalkan mantik (logika Aristoteles) ke dalam usul al-fiqh untuk menggantikan dasar-dasar epistemologi kalam yang biasa digunakan para ahli usul al-fiqh, dan mengenalkan teori maslahat dan metode munasabah dengan konsep pokok tentang spesies illat (nau' al-illah) dan jenis illat (jins al-'illah), serta spesies hukum (nau' al-hukm) dan jenis hukum (jins al-hukm). ${ }^{15}$

Pendekatan 'irfânî adalah pendekatan pemahaman yang bertumpu pada instrumen pengalaman batin: dzauq, qalb, wijdân, bashîrah dan ilhâm. Pengetahuan yang diperoleh melalui pendekatan ini biasanya disebut pengetahuan dengan

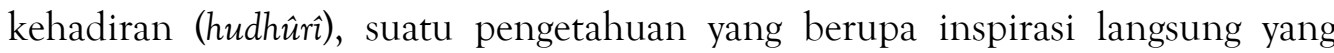
dipancarkan Allah ke dalam hati orang yang jiwanya selalu bersih. Pendekatan 'irfânî, walaupun ada kritikan, karena antara lain melahirkan tradisi sufi yang tidak dikenal dalam Muhammadiyah, bagaimanapun tetap ada gunanya. Intuisi dapat menjadi sumber awal bagi pengetahuan, setidaknya menjadi sumber inspirasi pencarian hipotesis. Dalam pengamalan agama dan bersikap baik terhadap orang lain, hati nurani dan kalbu manusia dapat menjadi sumber bagi

14 Djamil, Ibid.,

15 Syamsul Anwar, "Manhaj Ijtihad/Tajdid dalam Muhammadiyah," dalam Mifedwil Jandra dan M. Safar Nasir (ed.), Tajdid Muhammadiyah untuk Pencerahan Peradaban (Yogyakarta: MT-PPI PP Muhammadiyah bekerja sama dengan UAD Press, 2005), h. 63-81. 
kedalaman penghayatan agama, kekayaan rohani dan kepekaan batin. Sedangkan bagi ijtihad hukum, intuisi dan kalbu manusia dapat menjadi sumber pencarian hipotesis hukum, juga pembuktian akhir terletak pada bukti-bukti bayânî dan burhânî. ${ }^{16}$

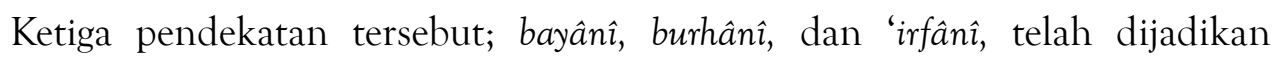
pedoman bagi warga Muhammadiyah dalam berpikir, terutama dalam memahami dan menyelesaikan masalah-masalah muamalah. ${ }^{17}$

Fase ketiga perkembangan pemikiran manhaj ijtihad Muhammadiyah menunjukkan upaya penyempurnaannya melalui penambahan dimensi filsafat ilmu. Syamsul Anwar, misalnya, menawarkan landasan epistemologi dalam pengertian luasnya, yaitu pra-anggapan dasar dalam pemikiran manusia tentang realitas. Landasan epistemologi manhaj ijtihad Muhammadiyah adalah inti pengalaman agama dalam Islam sendiri dan pandangan hidup Islami, yaitu tauhid. Secara metodologis, tauhid mengandung empat prinsip penting, di antaranya: (1) kesatuan kebenaran (wahdaniyyah al-haqîqah), (2) optimisme (attafâ'ul), (3) keragaman manifestasi (tanawwu'at-tajalliyât), dan (4) keterbukaan (alinfitâh), dan toleransi (at-tasâmuh). ${ }^{18}$

Kesatuan kebenaran, yang bersumber dari keyakinan tauhid bahwa Allah Maha Esa, berarti bahwa kebenaran dari berbagai sumber, baik dari wahyu Ilahi (al-bayân), dunia empiris (al-burhân), dan pengalaman batin manusia (al'irfân), adalah satu dan tidak ada pertentangan di antaranya. Optimisme maksudnya adalah keyakinan bahwa tiada kontradiksi yang abadi dan bahwa manusia mampu mencapai kebenaran karena ia telah dilengkapi Sang Pencipta dengan berbagai akal, budi pekerti, indera dan kalbu, dan kepadanya telah dikirim para rasul untuk menyampaikan kebenaran. Namun, harus diakui ada keterbatasan manusia sehingga ia hanya dapat menangkap beberapa sisi dari kebenaran tersebut. Karena itu, kebenaran ada yang bersifat mutlak (qath'̂े) dan ada yang bersifat nisbi (zhannî). Dengan demikian, manifestasi pengalaman agama dapat beragam, terutama dalam aspek muamalah, bahkan dalam wilayah ibadah (attanawwu' fî al-ibâdah) sepanjang tidak melanggar norma-norma. ${ }^{19}$

\footnotetext{
16 Anwar, Ibid.,

17 Lihat dalam Keputusan Muktamar Muhammadiyah, Pedoman Hidup Islami Warga Muhammadiyah, 2000.

18 Ibid.,

19 Ibid.,
} 
Toleransi berarti kelapangan (as-sa'ah) dan kemudahan (al-yusr), yang berarti bahwa kita dapat mempertahankan apa yang selama ini dianggap benar sampai ditemukan bukti baru yang menunjukkan kebalikannya, dan kita dapat meneruskan sesuatu yang selama ini kita buktikan baik sampai ditemukan bukti baru sebaliknya. Toleransi akan melindungi seseorang dari ketertutupan terhadap dunia, keragu-raguan dan kehati-hatian yang berlebihan yang menghambat kreativitas dan pembaruan pemikiran. Prinsip keterbukaan ini mendorong pencarian dan penerapan pengalaman baru yang konstruktif. Selain itu, prinsip ini berarti pula suatu keyakinan bahwa Tuhan tidak membiarkan hambanya tanpa petunjuk dan bahwa Tuhan melengkapi manusia dengan sensus numinis yang memungkinkannya untuk menangkap intisari kebenaran agama. ${ }^{20}$

Dalam rangka membangun sistem ijtihad, yang tersisa adalah landasan aksiologinya. Sebagai bekal awal, prinsip tujuan-tujuan syariah (maqâshid alsyarîah) dan prinsip maslahah yang sudah dikenal di kalangan ulama fiqih, dapat digunakan.

\section{Analisis}

Perkembangan dua pemikiran penting dalam Muhammadiyah, sebagaimana telah dijelaskan sebelumnya, menunjukkan dua corak perkembangan yang cukup berbeda. Perkembangan pemikiran tentang pemurnian Islam memperlihatkan corak siklus: spiritualisasi syariah, formalisasi syariah, spiritualisasi syariah (lihat Bagan 1). Sementara itu, perkembangan pemikiran tentang manhaj ijtihad Muhammadiyah memperlihatkan corak linear-konstruktif (lihat Bagan 1): Manhaj tarjih menjadi titik tolak perumusan pendekatan ijtihad, sementara pendekatan tarjih menyempurnakan manhaj tarjih. Pendekatan ijtihad menjadi titik tolak perumusan sistem ijtihad, sementara sistem ijtihad menyempurnakan pendekatan ijtihad. Titik tolak menjadi indikator linearitas dan penyempurnaan menjadi indikator konstruksi. Manhaj tarjih belum memperlihatkan konstruksi manhaj ijtihad Muhammadiyah yang utuh, sementara sistem ijtihad (setelah dilengkapi landasan aksiologi) memperlihatkan konstruksi manhaj ijtihad Muhammadiyah yang utuh.

20 Anwar, Ibid.; Isma'il R. al-Faruqi dan Lois Lamya al-Faruqi, The Cultural Atlas of Islam (New York: Macmillan Publishing Company, 1986). 


\section{BAGAN 1. PERBANDINGAN CORAK PERKEMBANGAN PEMIKIRAN DALAM MUHA MMADIYAH}

\section{Isu Pemurnian Islam}

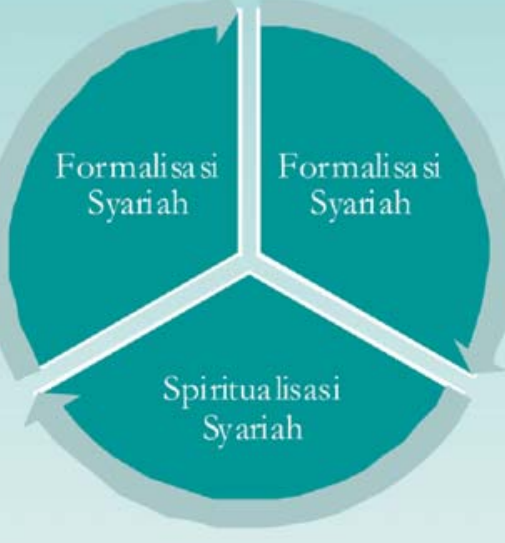

\section{Isu Manhaj Ijtihad}

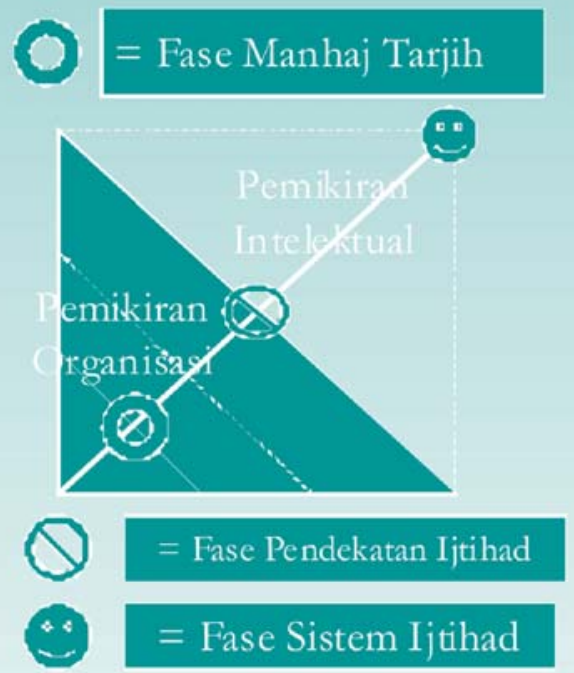

Bila perkembangan pemikiran tentang dua isu tersebut dibandingkan, maka pada fase spiritualisasi syariah babak pertama (masa Kiai Ahmad Dahlan) belum terumuskan sama sekali manhaj ijtihad Muhammadiyah. Meski demikian, hal itu bukan berarti tidak ada praktik ijtihad pada fase spiritualisasi syariah babak pertama. Beberapa respons yang bernas dari Kiai Ahmad Dahlan terhadap berbagai tantangan yang dihadapi (modernisme, tradisionalisme, dan Jawaisme), berupa pendirian sekolah dan kepanduan, demitologisasi, dan tablig yang menghapuskan kramatisasi ulama dan mistifikasi agama, menunjukkan praktik

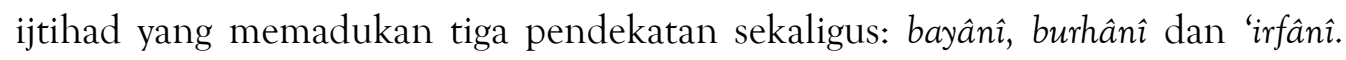
Ahmad Dahlan merespons tantangan modernisme (pendirian sekolah dan kepanduan) didekati dengan pendekatan bayânî dan burhânî, sementara respons terhadap Jawaisme (berupa demitologisasi) dan tradisionalisme (berupa tablig yang secara tersamar menghapus kramatisasi ulama dan mistifikasi agama) didekati dengan pendekatan bayânî dan 'irfân̂̀ (lihat Bagan 2). 
BAGAN 2. PERBANDINGAN KOHERENSI FASE

ISU PEMURNIAN ISLAM

ISU MANHAJ IJTIHAD
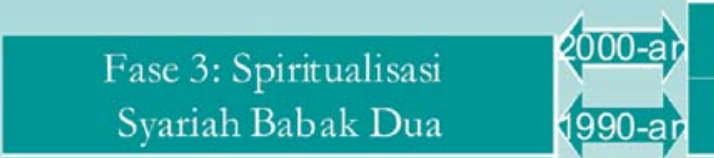

Fase 3: Sistem Ijtihad

Fase 2: Pendekatan Ijtihad
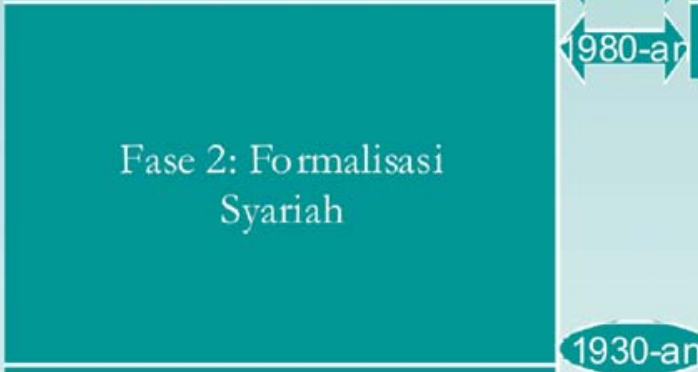

Fase 1: Manhaj Tarjih

Fase 1: Spiritualisasi

Syariah Babak Satu

1930-an

1910-an

Fase pertama perumusan manhaj, yaitu fase manhaj tarjih, baru terjadi pada fase kedua perkembangan pemikiran Islam tentang pemurnian Islam (yaitu fase formalisasi syariah). Dalam hal ini, tampak kesejajaran antara kedua fase tersebut (lihat Bagan 2). Adalah wajar bila pada fase formalisasi syariah, yang baru bisa dihasilkan adalah manhaj tarjih yang lebih menekankan ijtihad di bidang hukum Islam. Koherensi dan kesejajaran tampak juga antara fase kedua perumusan manhaj ijtihad (yaitu fase pendekatan ijtihad) dan fase ketiga perkembangan pemikiran tentang pemurnian Islam (fase spiritualisasi syariah babak kedua) (lihat Bagan 2). Spiritualisasi syariah babak kedua memungkinkan perumusan pendekatan ijtihad yang lebih luas, tidak terbatas pada ijtihad di bidang hukum Islam, namun merambah ke sejumlah bidang lain. Lebih jauh dari itu, spiritualisasi syariah babak kedua memungkinkan perumusan yang lebih sistemik tentang manhaj ijtihad Muhammadiyah. 


\section{Penutup}

Kalau sejak menjelang Muktamar ke-45 di Malang (2005) hingga paska Muktamar, karena tantangan globalisasi, muncul fenomena dialektika pemikiran di Muhammadiyah antara konservatif dan liberal (penamaan datang dari pengamat atau lawan dialektika), maka dengan menggunakan tulisan ini dapat dibaca bahwa fenomena tersebut tengah memperlihatkan dialektika antara spiritualisasi syariah dan formalisasi syariah. Spiritualisasi syariah memperoleh tantangan dari formalisasi syariah.

Sikap dan harapan kita, warga Muhammadiyah, terhadap fenomena dialektika pemikiran tersebut, dapat dikembalikan ke landasan espistemologi ijtihad Muhammadiyah yang ditawarkan, yaitu sikap optimis, yakin bahwa tidak ada kontradiksi yang abadi, termasuk dialektika antara sayap konservatif dan liberal. Adapun dialog sebagai perwujudan dari prinsip keterbukaan dan toleransi, dan prinsip mengakui keragaman manifestasi, terus dilakukan. Dengan dialog terus menerus, dimungkinkan akan lahir pembaruan pemikiran yang baru.

Terkait dengan gagasan internasionalisasi pemikiran dan gerakan Muhammadiyah di tengah tantangan global yang beragam dimensi, maka situasi sekarang terkait dengan isu permunian Islam dan isu manhaj ijtihad, yang berada pada fase spiritualisasi syariah babak kedua dan fase pembentukan sistem ijtihad, merupakan situasi yang kondusif bagi upaya internasionalisasi pemikiran dan gerakan Muhammadiyah.

\section{Bibliografi}

Abdullah, M. Amin, "Perkembangan Pemikiran Islam dalam Muhammadiyah: Perspektif Tarjih Pasca Muktamar Muhammadiyah Ke-43," dalam Berita Resmi Muhammadiyah, No. 05/1995-2000 (April 1996), h. 18-26.

Anwar, Syamsul, "Manhaj Ijtihad/Tajdid dalam Muhammadiyah," dalam Mifedwil Jandra dan M. Safar Nasir (ed.), Tajdid Muhammadiyah untuk Pencerahan Peradaban, Yogyakarta: MT-PPI PP Muhammadiyah bekerja sama dengan UAD Press, 2005, h. 63-81.

Djamil, Fathurrahman, "Tajdid Muhammadiyah pada Seratus Tahun Pertama", dalam Mifedwil Jandra dan M. Safar Nasir (ed.), Tajdid Muhammadiyah untuk Pencerahan Peradaban, Yogyakarta: MT-PPI PP Muhammadiyah bekerja sama dengan UAD Press, 2005, h. 83-106.

al-Faruqi, Isma'il R. dan Lois Lamya al-Faruqi, The Cultural Atlas of Islam, New 
York: Macmillan Publishing Company, 1986.

Kuntowijoyo, Identitas Politik Umat Islam, Bandung: Mizan bekerja sama dengan Majalah Ummat, 1997.

Kuntowijoyo, "Pengantar: Jalan Baru Muhammadiyah", dalam Abdul Munir Mulkhan, Islam Murni dalam Masyarakat Petani, Yogyakarta: Bentang, 2000.

Mulkhan, Abdul Munir, Islam Murni dalam Masyarakat Petani, Yogyakarta: Bentang, 2000.

Sazali, Muhammadiyah $\mathfrak{E}$ Masyarakat Madani, Jakarta: Pusat Studi Agama dan Peradaban (PSAP) Muhammadiyah, 2005.

Shobron, Sudarno (ed.), Studi Kemuhammadiyahan: Kajian Historis, Ideologi dan

Organisasi, Surakarta: Lembaga Pengembangan Ilmu-Ilmu Dasar (LPID) Universitas Muhammadiyah Surakarta, 2006.

Syamsuddin, Din, "Studium General Kolokium Nasional Pemikiran Islam PSIF UMM dan Al-Maun Institute" http://www.muhammadiyah.or.id/ (diakses pada 30 Oktober 2014). 